\title{
Reality and Prospect: How does China Judge Choose Constitutional Remedy
}

\author{
Kai Chen \\ School of Law, Xiamen University, Xiamen 361005, China. \\ xmuchenkai@gmail.com
}

Keywords: China, judge, constitutional remedy, functionalism.

\begin{abstract}
When a judge finds that a statute violates the Constitution, the statute must be under investigated. According to the theory of Presumption of Constitutionality, the following question is how the judge will choose constitutional remedy. There are two types in relation to constitutional remedy: one is "Editorial Restraint", the other "Purpose Preservation". This Article explores China cases including the key words "constitution", "violate/violating constitution", and "violation of the constitution", and explains all relevant norms, showing that "Editorial Restraint" is the China type of constitutional remedy. The Article then argues that the functionalism approach is the superior way for China judge to choose constitutional remedy, namely, functionalism approach, while can enhance China judge's power in choosing constitutional remedy, focuses on the function of the judges' interpretation action, which strongly act on the whole judicial structure and legal system. This Article has two contributions, one is that it concludes "Editorial Restraint" is the type of constitutional remedy in China, even though not typical; the other is that it leads a functionalism approach for choosing constitutional remedy.
\end{abstract}

\section{Introduction}

Generally speaking, when a judge finds that a statute violates the Constitution, the statute must be declared invalid, not apply, severed, or handled by other ways. In a word, the statute must give way. Under this circumstance, the first action the judge may choose is giving birth to the statute, rather than ending statute's life up. In other words, judges have to choose certain ways to remedy the conflict between the Constitution and the statute. There are at least two pure types we can choose, the one is the English approach: "Editorial Restraint", by which "judges should assume as little power to change legislation as possible"; the other is the Canadian Approach: "Purpose Preservation", by which "focuses instead on finding the remedy that does the least damage to the legislature's goals." ${ }^{[1]}$ How may China judge do in this situation: choosing the "Editorial Restraint" or "Purpose Preservation", or adopting a new way unlike the two above?

This Article explores whether China judges have the power to interpret laws and what kind of judicial review in China. Part 2 seeks to discuss in two aspects which type of choosing constitutional remedy is belong to China. This Article claims that we cannot find out the answer until going through China judicial cases and reading the provisions of administrative procedure law of China. Part 3 attempts to predict the future prospect of China constitutional remedy choice. Finally, this Article maintain the reality of China constitutional remedy is constrained, yet there has a huge space for constitutional remedy development. The last thing we are concerned is the role of China judges in constitutional remedy.

\section{Judicial Review and Judge's Interpretation Right in China}

\subsection{The Democratization of China Judicial Review.}

China judicial review and the resolution mechanism of legislative conflict are very different from western countries. In theory, China National People's Congress(CNPC) enjoys the right of judicial review and resolution of the legislative conflict. Article 62 of China Constitution provides that CNPC has power to supervise the enforcement of the Constitution. ${ }^{[2]}$ Therefore, since CNPC was elected by the people in China, CNPC as the body of constitutional review bears democratization. 
However the current Constitution had enacted and implemented over more than 20 years, there was none Act or administrative laws or local regulations that had been declared unconstitutional. ${ }^{[3]}$

\subsection{The Empty of China Judicial Authority on Interpretation.}

According to Article 62 and 67 of China Constitution, CNPC Standing Committee exercises the authority of "constitutional interpretation" and "interpreting the laws". ${ }^{[4]}$ Thus, based on the text of the Constitution, the judiciary has no power of judicial interpretation in China. In China, judge's authority on interpretation is confined to the application of law, rather than the content of law. That's why the judiciary in China is unable to get his hands on judicial review. ${ }^{[5]}$ Due to the interpretation by judges only has applicability rather than a substantive, it seems that the interpretation is not determinant.

Does this means that the China type of constitutional remedy is not existing? If not, what is the truth? Next section will analysis this issue in two aspects that are case study and legal norms.

\section{How does China Judge Choose Constitutional Remedy: Case Study and Legal Norm}

\subsection{Can Positivistic Case Study Answer Our Question?}

Case study focus on the claimant's appeals and the behavior of China judge. In this section we will raise and resolve two problems.

The first one is that did claimant arouse constitutional challenge? If claimant do not raise an issue of the constitutionality of the law, the court will decide cases almost without considering judicial review, let alone declaring certain provisions invalid. Even the China judge cannot declare certain provisions violating Constitution invalid. Given all that, will case study actual end the question? Due to this reason, this Article searched on the case database of "PKU Law" by the key words "violate/violating constitution" or "violation of the constitution", and classified the outcome according to different standards, as showing by Figure 1:

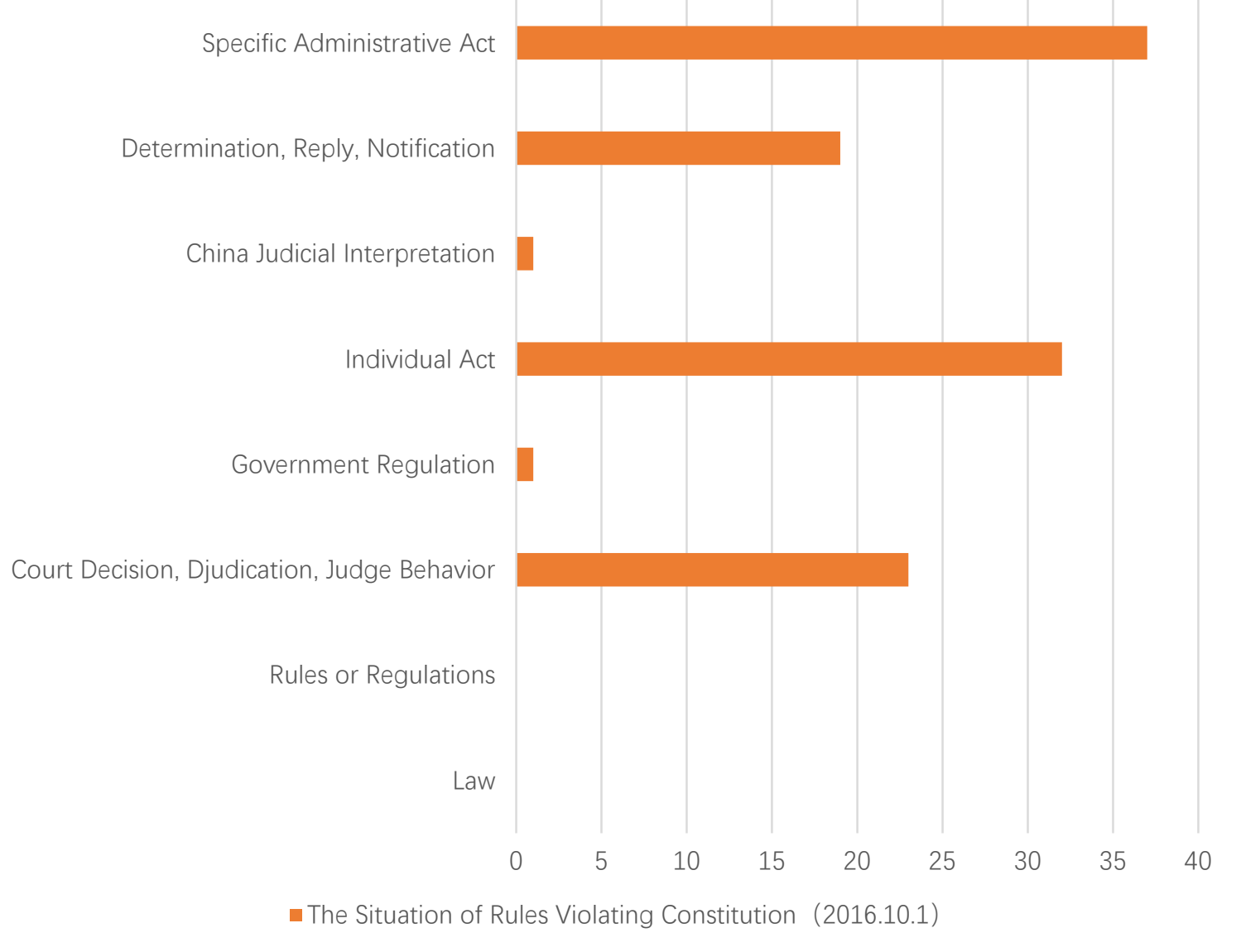

Fig. 1 Did Claimant Arouse Constitutional Challenge?

The essential picture is immediately clear: one may file suits claiming that “...determination”, 
“...reply”, or “...notification” is unconstitutional; ${ }^{[6]}$ claiming that "court decision”, "adjudication”, or "a judge behavior" violates Constitution; ${ }^{[7]}$ claiming that "the specific administrative act" violates Constitution; ${ }^{[8]}$ claiming that "an individual act" violates Constitution; ${ }^{[9]}$ claiming that "China Judicial Interpretation" is unconstitutional; ${ }^{[10]}$ it is really surprised that no one file suits claiming that "Laws, rules or regulations" violates Constitution. As a result, unfortunately, in absent of practical cases we cannot successfully conclude which type of constitutional remedy China judge would choose.

The second one is that did China judge quote Constitution to judge a case and can that solve our puzzle and mysteries? In practice, China Judge often quotes and interprets Constitution, it seems that they are very keen on interpreting Constitution, at the same time scholars strongly encourage such behavior. Hence, this Article searched on the case database of "PKU Law" by the key words "Constitution", ${ }^{[11]}$ and classified the outcome according to the level of courts, as showing by Figure 2:

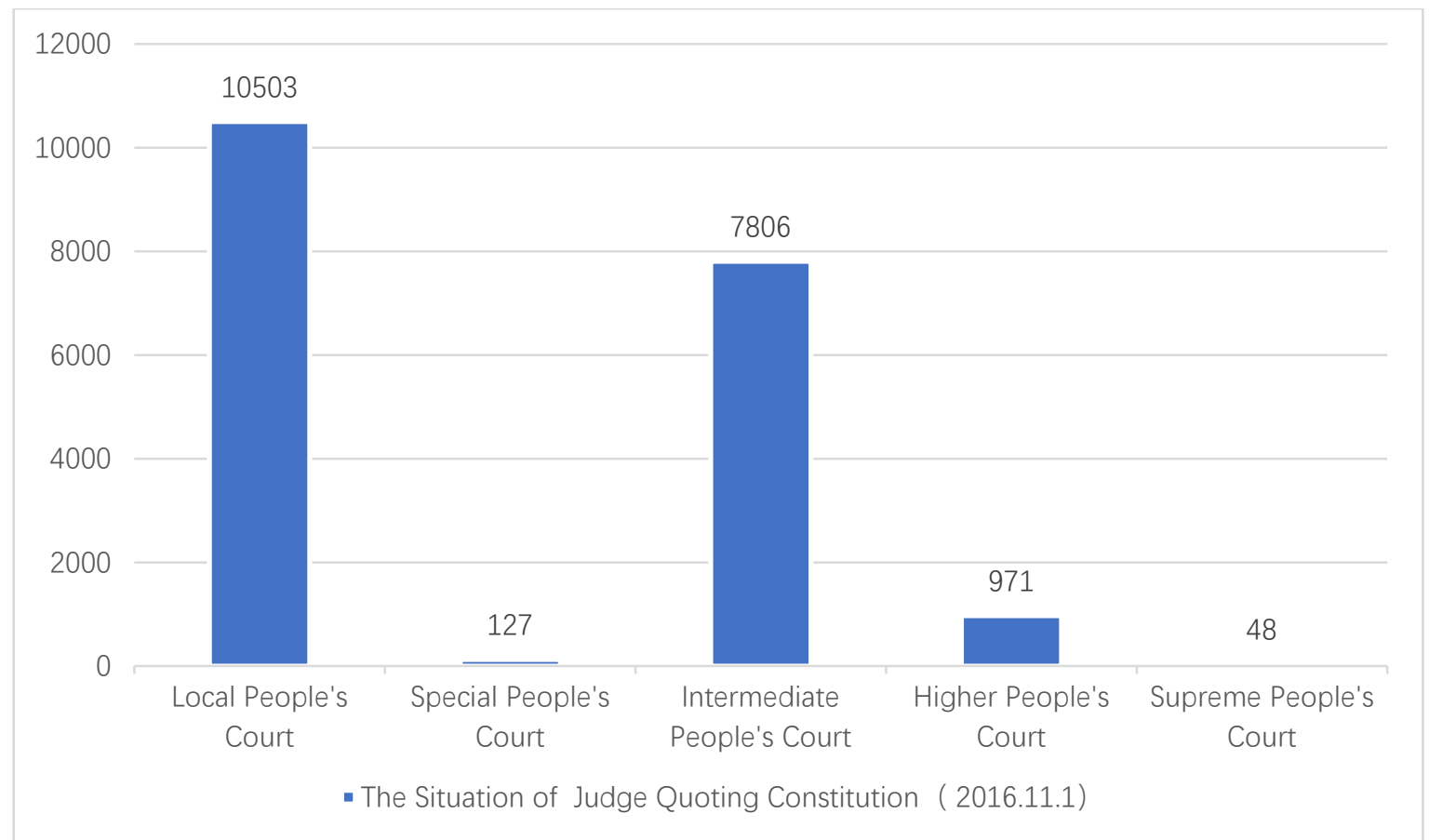

Fig. 2 Did China Judge Quote Constitution to Judge a Case?

The essential picture is immediately clear: it is intelligible that China Judge frequently quotes Constitution. Nonetheless we fail to tell what is the type of constitutional remedy China Judge has chosen, for two reasons. First, the Constitution quoting by China Judge is not really effective, the clincher is the law, but sometimes the Constitution may lead to the judgement. ${ }^{[12]}$ It is obvious that the quoting and interpreting does not involve choosing remedy. Second, China Judge frequently quotes and interprets Constitution, the aim of this action is not to interpret the content of law. Furthermore, there is little correlation between that aim and remedy choosing. Actually, even if the judge found that the law conflicts with the Constitution, he would easily resolve the inconsistence by taking a general explanation. ${ }^{[13]}$

\subsection{A Sub-Optimal Based on Legal Norm: Editorial Restraint.}

If case study cannot offer a proper answer, it seems that we must ask for plan B: it can explore how does China judge choose remedy when he finds that a document violates the Constitution or law.

First, the relevant provisions of the Legislation Law of PRC read as follows: “...Supreme People's Court...believes that administrative laws and regulations, or local regulations, or self-government ordinances, or separate regulation, violate the Constitution or law... (the specific regulations or others) can be submitted to National People's Congress Standing Committee in a written request for review...” [14]

Second, the relevant provisions of the China Administrative Procedural Law read as follows: "if people's courts in handling administrative cases believe that... Normative Documents (does not 
contain regulations) violates the Law, the law cannot be the legal basis judgement of administrative action..."

In this way, it is not difficult to draw a conclusion that China judges "should assume as little power to change legislation as possible". As a result, "Editorial Restraint" is China type of constitutional remedy, even though not very typical.

\section{Prospect of China Judge Choose Constitutional Remedy}

As mentioned above, China type of constitutional remedy seems to be "Editorial Restraint". However, this Article attempts to set forth a new argument is that we should not be limited to "Editorial Restraint" or "Purpose Preservation”. On the contrary, we must resort to a functionalism approach for re-examining China type of constitutional remedy. Functionalism approach focuses on the function of the judge's interpretation action, which strongly act on the whole judicial structure and legal system. Functionalism approach can break down the Discretionary Determinism, while the type of constitutional remedy depends on judge's discretion. Thus functionalism approach may be the bright prospect of China judge choose constitutional remedy.

\section{Conclusion}

When a judge finds that a statute violates the Constitution, the statute must be under investigated, and he will face two types of choices: "Editorial Restraint" or "Purpose Preservation". As to the types of judge choosing constitutional remedy in China, this Article finds out China type of choosing constitutional remedy belong to "Editorial Restraint" through searching and studying judicial precedent. Finally, this Article maintains that functionalism approach may be the bright prospect for China's current practice.

\section{References}

[1]. Eric S. Fish, Choosing Constitutional Remedies, 63 UCLA L. Rev. 322 (2016), p. 322-330.

[2]. The Constitution of the People's Republic of China, Article 62.

[3]. Miao Lian-ying. Examining Violation of Constitution in China ---Is it possible and how to make it possible ? Journal of Zhengzhou University (Philosophy and Social Science Edition), Vol. 37 (2004) No. 4, p.47.

[4]. The Constitution of the People's Republic of China, Article 62, 67.

[5]. Wang Bin. The Implementation of the Constitution of China. Global Law Review, Vol. 35 (2013) No. 5, p.37-38.

[6]. For example, Cai Wenshu vs. Wenzhou Municipal Bureau for Letters and Calls. CLI.C.8321409.

[7]. For example, Li Shiyong and Peng Dingqian Disputes of the Sale and Purchase Contract. CLI.C.7827661.

[8]. For example, Xu Qiangjun vs. Tonglu County People’s Government. CLI.C.8353533.

[9]. For example, Lin Heping vs. Guan Qiao Zhen, Anxi County People's Government. CLI.C.6731186.

[10]. For example, Qiu Jiandong vs. Ministry of Justice of the People's Republic of China. CLI.C.16685670.

[11]. This Article assumed that if one case quoted "Constitution" at once, this case had have used and applied the Constitution.

[12]. Xing Bin-wen. How the Court Invoked the Constitution, China Law Review, Vol. 2 (2015) No. 5, p. 155.

[13]. Fan Zhong-xin. The Chinese Review of Constitutionality and the Mechanisms of Legislative Conflict Resolution”, Law Science (Journal of Northwest Institute of Political Science and Law), Vol. 114 (2001) No. 6, p. 47.

[14]. The Legislation Law of the People’s Republic of China, Article 99. 